\title{
Effects of Continuous Vertical Soil Pores on Root and Shoot Growth of Winter Wheat: A Microcosm Study
}

\author{
Tim Dresemann', Miriam Athmann',2, Lukas Heringer1, Timo Kautz ${ }^{3}$ \\ ${ }^{1}$ INRES-Agroecology and Organic Farming, University of Bonn, Bonn, Germany \\ ${ }^{2}$ Experimental Farm Wiesengut, Hennef, Germany \\ ${ }^{3}$ INRES Soil Science, University of Bonn, Bonn, Germany \\ Email: tkautz@uni-bonn.de
}

How to cite this paper: Dresemann, T., Athmann, M., Heringer, L. and Kautz, T. (2018) Effects of Continuous Vertical Soil Pores on Root and Shoot Growth of Winter Wheat: A Microcosm Study. Agricultural Sciences, 9, 750-764.

https://doi.org/10.4236/as.2018.96053

Received: May 11, 2018

Accepted: June 24, 2018

Published: June 27, 2018

Copyright $\odot 2018$ by authors and Scientific Research Publishing Inc. This work is licensed under the Creative Commons Attribution International License (CC BY 4.0).

http://creativecommons.org/licenses/by/4.0/

\begin{abstract}
Round shaped, continuous vertical pores (CVPs) in the soil are typically created by roots and earthworms. CVPs with diameters $>2 \mathrm{~mm}$ are abundant in many agricultural soils. We hypothesized that potential effects of CVPs on shoot growth of winter wheat (Triticum aestivum L.) increase with: 1) decreasing availability of water and 2) decreasing availability of nutrients in the topsoil. We conducted a microcosm experiment with different irrigation regimes (Irr+/Irr-) and $\mathrm{P}$ concentrations $(\mathrm{P}+/ \mathrm{P}-)$, with or without artificially created continuous vertical pores (CVP+/CVP-). Winter wheat was cultivated for 16 weeks. In the bulk soil, presence of CVPs resulted in decreased root length in $20-40 \mathrm{~cm}$ but increased root length in $40-60 \mathrm{~cm}$ soil depth. In general, total root length of winter wheat in $20-60 \mathrm{~cm}$ soil depth was higher when CVPs were present or when P concentrations in the topsoil were elevated. Presence of CVPs generally had a positive effect on shoot dry matter and $\mathrm{N}$ uptake of wheat. In columns with high phosphorous concentrations but low soil moisture in the topsoil, presence of CVPs increased shoot dry matter by $66 \%$; in contrast, the beneficial effect of CVPs on shoot dry matter was only $39 \%$ in columns with high nutrient concentrations and high soil moisture in the topsoil. In total numbers, however, the effect of CVPs on P uptake into the shoot was more pronounced when $\mathrm{P}$ concentrations in the topsoil were elevated. We conclude that CVPs can promote the exploration of the solid soil phase by high root-length densities, but adequate nutrient supply in the topsoil is essential.
\end{abstract}

\section{Keywords}

Subsoil, Mechanical Resistance, Drought Stress, P Supply, Nutrient Acquisition 


\section{Introduction}

Biopores are voids in the soil created by soil organisms including earthworms and plant roots [1]. This paper deals with round shaped, continuous pores and a more or less vertical orientation in the soil profile. Studies with radionuclides released during nuclear weapon tests in the 1950s and 1960s indicate that preferential flow along macropores is persistent with time [2]. In arable topsoils, continuous vertical pores (CVPs) are frequently destroyed by tillage operations, but they potentially remain stable probably for decades below the plough horizon. CVPs are preferential pathways for root growth in the subsoil, especially when high mechanical resistance limits root elongation through the bulk soil [3] [4]. Beyond that, CVPs can enhance air transport in soils [5] and water percolation, reducing the risk of water ponding or water runoff from the surface [6]. In turn, water flow through CVPs was shown to increase the transport of solutes such as nitrate, dissolved $\mathrm{P}$ and plant protection agents towards the ground water body [7] [8] [9]. Potential beneficial effects of CVPs on crop growth are particularly related to their function as preferential pathways for root elongation. On the one hand, increased rooting depth via facilitated root growth through CVPs can be crucial for crop performance during dry spells: when high penetration resistance impedes root growth through the bulk soil, accelerated access to the subsoil via CVPs could enhance the ability of crops to explore water resources [10]. This applies particularly to spring crops, which depend on developing their root system in a comparatively short period of time. Since model predictions suggest severe drought conditions by the late half of this century over many areas such as Europe, the eastern USA, southeast Asia and Brazil [11], such processes will probably be of increased relevance in the future.

On the other hand, CVPs may increase the subsoil's contribution to crop nutrition: pore walls are often enriched in plant nutrients such as $\mathrm{N}$ and $\mathrm{P}$ [12] [13] [14], which probably also makes them favored locations of nutrient uptake. Furthermore, if roots can cross the pore wall, CVPs can promote root-length density in the bulk soil and hence potentially increase access to the nutrients stored therein [15]. However, improved sub-soil structure following cultivation of taprooted crops was also reported to have either small or no effects on the yield of subsequent crops [16]. Roots growing through pores larger than their own diameter are at least partially exposed to air [17], and depending on soil conditions, the relative impermeability of the pore wall can prevent roots from growing out of the pore into the bulk soil [18], thus causing clumping of roots in CVPs. Even if roots can cross the pore wall and increased CVP density results in greater overall root-length density, shoot growth is not necessarily promoted, because establishing deep and extended root systems requires significant amounts of energy and assimilation [19] [20]. For crops well provided with available nutrients and water, extended root systems in the subsoil may merely decrease the shoot: root ratio rather than increased aboveground yields. In contrast, in low-input farming systems like organic agriculture, relying on mobiliza- 
tion of nutrients from the solid phase rather than mineral fertilization, it is a general aim to support large root-length densities [21]. Thus, CVPs can be expected to improve crop nutrition especially in these production systems.

The contribution of the subsoil to crop nutrition in general depends on water stress and availability of plant nutrients [22]. To our knowledge, the effects of CVPs in the subsoil on shoot biomass of crops have not been studied before in interaction with availability of water and nutrients. We hypothesized those potential effects of CVPs on shoot growth of winter wheat increase when: 1) availability of water decreases and 2) availability of nutrients in the topsoil decreases.

Our hypotheses could not be tested under field conditions, particularly because of uncertainties regarding the field heterogeneity of the soil structure and difficulties with controlling soil moisture. Hence we conducted a pot experiment under controlled conditions using three-stage columns with a top segment containing soil with different moisture and nutrient contents, a middle segment with or without artificial pores and a lower segment providing water saturated soil.

\section{Materials and Methods}

\subsection{Experimental Design}

A multifactorial microcosm experiment was established with two different phosphorus concentrations in the topsoil $(\mathrm{P}+/ \mathrm{P}-)$, irrigation $(\mathrm{Irr}+/ \mathrm{Irr}-)$ and presence of continuous vertical pores in the subsoil (CVP+/CVP-) as factors. The experiment was conducted in PVC-pipes with an inner diameter of $19 \mathrm{~cm}$ and a total height of $85 \mathrm{~cm}$ (Figure 1). Upper segments (height: $20 \mathrm{~cm}$ ), were filled with topsoil from plots of field experiments with $\mathrm{P}$ deficiency (research farm "Dikopshof", University of Bonn) or elevated P concentrations (experimental station "Campus Klein Altendorf", University of Bonn). For all treatments, middle and lower segments (height: 45 and $20 \mathrm{~cm}$ ) were filled with subsoil from the latter site. Both soils have developed from Weichselian loess. Detailed information about soil properties is listed in Table 1. Mean annual temperature and annual precipitation are $9.7^{\circ} \mathrm{C}$ and $630 \mathrm{~mm}$ at "Dikopshof" and $9.6^{\circ} \mathrm{C}$ and $625 \mathrm{~mm}$ at "Campus Klein Altendorf". Topsoil and subsoil were sieved to 5 and $2 \mathrm{~mm}$ prior to experimentation. Soil in upper and lower

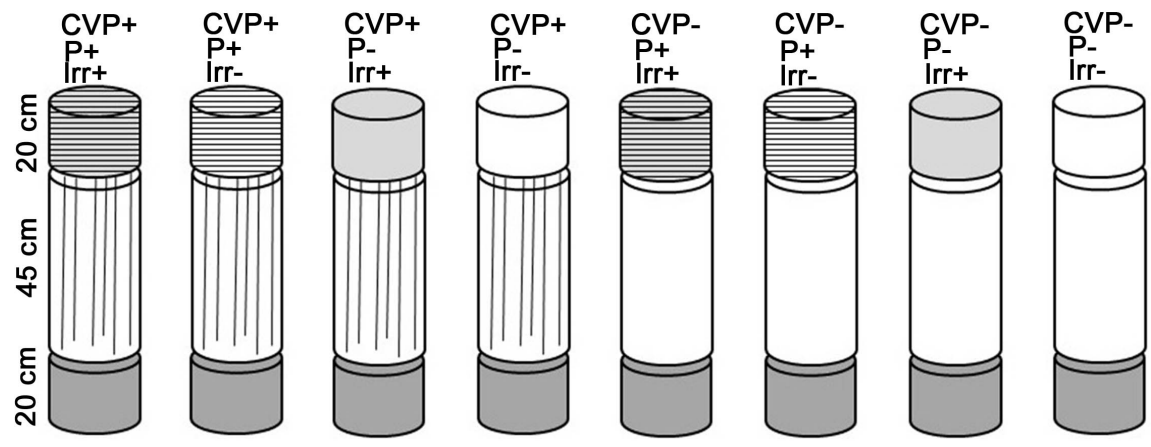

Figure 1. Schematic view on the treatments of the microcosm experiment. 
Table 1. Properties of soil used in microcosm experiment.

\begin{tabular}{ccccccccc}
\hline $\begin{array}{l}\text { Field } \\
\text { trial }\end{array}$ & Treatment & $\begin{array}{c}\text { Excavation } \\
\text { depth }(\mathrm{cm})\end{array}$ & $\begin{array}{c}\text { Sand } \\
(\%)^{\mathrm{b}}\end{array}$ & $\begin{array}{c}\text { Silt } \\
(\%)^{\mathrm{b}}\end{array}$ & $\begin{array}{c}\text { Clay } \\
(\%)^{\mathrm{b}}\end{array}$ & $\begin{array}{c}\mathrm{C}_{\text {tot }} \\
\left(\mathrm{g} \cdot \mathrm{kg}^{-1}\right)\end{array}$ & $\begin{array}{c}\mathrm{N}_{\text {tot }} \\
\left(\mathrm{g} \cdot \mathrm{kg}^{-1}\right)\end{array}$ & $\begin{array}{c}\mathrm{P} \\
(\mathrm{mg} / 100 \mathrm{~g})\end{array}$ \\
\hline $\mathrm{DIK}$ & $\mathrm{P}-$ & $0-20$ & 25 & 60 & 15 & 0.93 & 0.10 & 4.63 \\
$\mathrm{CKA}$ & $\mathrm{P}+$ & $0-20$ & 8 & 77 & 15 & 1.04 & 0.11 & 9.55 \\
$\mathrm{CKA}$ & all & $45-75$ & 4 & 69 & 27 & 0.49 & 0.06 & 1.72 \\
\hline
\end{tabular}

a'DIK: "Dikopshof”; CKA: “Campus Klein Altendorf”; 'Soil texture according to: [23] and [24].

segments was moderately compacted to bulk densities of approximately 1.3 $\mathrm{g} / \mathrm{cm}^{3}$. Soil in the middle segment was compacted to approximately $1.6 \mathrm{~g} / \mathrm{cm}^{3}$. We used a modified hydraulic device originally designed to lift hey-bales. Soil was compressed with a round "stamp" neatly fitting into the tubes. In order to achieve a more evenly distributed compaction, we pressed each soil column in 3 steps. In half of the middle segments (CVP+) 6 artificial vertical pores were created with an electric drill (diameter: $8 \mathrm{~mm}$ ).

A gauge was used to make sure that the pores were equally distributed in each of the columns. The density of vertical pores is equivalent to approximately 210 pores $\mathrm{m}^{-2}$, corresponding to a density of approximately $149-256$ coarse pores $\mathrm{m}^{-2}$ previously reported for the soil under study [25]. Artificial pores created with an electric drill can have surface properties different from natural pores. Thus, before cultivation we introduced earthworms into the pores in order to provide more natural pore wall properties. Each pore was incubated with an adult dew worm (Lumbricus terrestris L.) for 4 weeks. Worms were equally distributed over the columns according to their body mass. Each pore opening was closed with a perforated plastic cup to prevent worms from escaping. $0.3 \mathrm{~g}$ of dried lucerne-grass cut to $2 \mathrm{~mm}$ was placed under each plastic cup as a food source for earthworms. The litter was replaced when approximately half of the material was removed. Overall, up to $1.65 \mathrm{~g}$ of lucerne-grass mulch per pore were fed during the incubation. At the end of the incubation period of four weeks all worms were removed from the pores by warming up the column segments in a water bath to approximately $33^{\circ} \mathrm{C}$. Columns without artificial pores were treated in the same way; in particular, they were stored in the same room during incubation and warmed up in a water bath after incubation. Before cultivation, lower column segments were soaked in tap water in order to provide a source of water in the deep subsoil. The top of the lower and middle segments were covered with approximately $3 \mathrm{~cm}$ layers of gravel (particle size 7 - $15 \mathrm{~mm}$ ), to avoid capillary rise. Finally, the column segments were assembled and connected with duct tape.

\subsection{Cultivation}

12 seeds of winter wheat ( Triticum aestivum L.) "Graziaro" were sown into each column corresponding to a seeding density of 422 grains $\mathrm{m}^{-2}$. In total, wheat was cultivated for 16 weeks. During the first 12 weeks, columns were set up in a 
greenhouse at ambient temperature. At seeding, columns from all treatments were irrigated with $30 \mathrm{ml}$ tap water to allow equal emergence. Thereafter, Irr+ columns were irrigated twice a week with $30 \mathrm{ml}$ tap water, whereas irrigation in the Irr-columns was ceased. During the last 4 weeks of the experiment, drought stress was induced using fan heaters and $400 \mathrm{~W}$ mercury-vapor lamps for 12 $\mathrm{h} /$ day. The temperature amplitude at plant height was $20^{\circ} \mathrm{C}-30^{\circ} \mathrm{C}$. Columns from the Irr+ treatment were daily irrigated with $30 \mathrm{ml}$ tap water for two weeks. Since drought symptoms became visible, irrigation was increased to $100 \mathrm{ml}$ tap water/d for the last two weeks.

\subsection{Soil, Shoot and Root Analyses}

Shoot biomass was measured as dry matter with oven drying $\left(65^{\circ} \mathrm{C}\right) . \mathrm{C} / \mathrm{N}$ and $\mathrm{P}$ contents of soil and plant samples were measured using dry combustion with a Fisons NA-1500 elemental analyzer and atomic absorption spectrometry (AAS), respectively. Leaf area index was determined with a LI-3100 Area Meter (LI-COR Inc., USA). Middle segments of columns were horizontally dissected into 4 slices, representing soil depths of $20-30,30-40,40-50$ and $50-60 \mathrm{~cm}$. Slices containing artificial pores were sampled as follows.

Each pore was laterally opened using sharp knives. Roots growing inside of the pore lumen were carefully collected with a pair of tweezers. If necessary, roots were separated from the pore wall with a scalpel. The remaining samples were soaked in tap water and washed over a sieve (mesh size: $0.5 \mathrm{~mm}$ ) in order to separate roots from mineral particles an organic debris. The samples were further sorted to remove any non-root material. Immersed roots were carefully placed on trays in order to avoid overlapping and scanned with $800 \mathrm{dpi}$ using a Perfection V700 Photo scanner (Epson Corp.). Root-length density (cm roots $\mathrm{cm}^{-3}$ soil) was determined with the software package WhinRhizoPro 2016 (Regent Instruments Inc.). Soil from columns without artificial pores was directly soaked in tap water. Roots were washed and scanned as described above.

\subsection{Statistics}

Data were checked for normality with Shapiro-Wilk tests. Since normality was generally given, means were compared without previous transformation by multifactorial ANOVA with continuous vertical pores (CVP), P supply in the topsoil (P) and Irrigation (Irr) as fixed factors and block effect as random factor. Means of shoot parameters were additionally compared on single treatment level by one factorial ANOVA with Tukey tests. All statistical analyses were done with IBM SPSS Statistics Version 25.

\section{Results and Discussion}

\subsection{Root Length}

Total root length of winter wheat in $20-60 \mathrm{~cm}$ soil depth was higher when continuous vertical pores were present (Figure 2, Table 2). The magnitude of this 


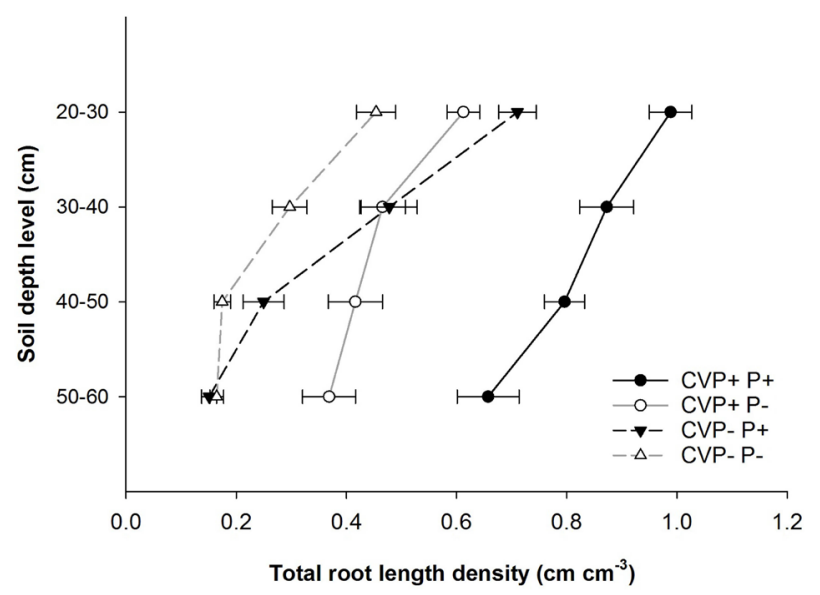

Figure 2. Total root-length density averaged over all irrigation treatments. CVP: Continuous vertical pores; P: P supply in the topsoil. Error bars represent standard errors.

Table 2. Univariate statistics: Comparison of means by multifactorial ANOVA with continuous vertical pores (CVP), P supply in the topsoil (P) and Irrigation (Irr) as fixed factors and block effect as random factor. P-values $<0.05$ are highlighted in bold.

\begin{tabular}{ccccccccc}
\hline Variable & CVP & P & Irr & CVP $\times$ P & CVP $\times$ Irr & P $\times$ Irr & CVP $\times$ P $\times$ Irr & Block \\
\hline Shoot dry mass & $\mathbf{0 . 0 0 0}$ & $\mathbf{0 . 0 0 0}$ & $\mathbf{0 . 0 0 0}$ & $\mathbf{0 . 0 0 0}$ & 0.126 & 0.630 & 0.880 & 0.416 \\
N uptake & $\mathbf{0 . 0 0 0}$ & $\mathbf{0 . 0 0 0}$ & $\mathbf{0 . 0 0 1}$ & $\mathbf{0 . 0 0 7}$ & 0.240 & 0.293 & 0.451 & 0.409 \\
P uptake & $\mathbf{0 . 0 0 0}$ & $\mathbf{0 . 0 0 0}$ & $\mathbf{0 . 0 0 0}$ & $\mathbf{0 . 0 0 3}$ & 0.351 & $\mathbf{0 . 0 0 1}$ & 0.659 & 0.881 \\
Leaf area index & $\mathbf{0 . 0 0 0}$ & $\mathbf{0 . 0 0 0}$ & $\mathbf{0 . 0 0 0}$ & $\mathbf{0 . 0 0 1}$ & 0.493 & 0.981 & 0.957 & 0.776 \\
RLD $(20-30 \mathrm{~cm})$ & $\mathbf{0 . 0 0 0}$ & $\mathbf{0 . 0 0 0}$ & 0.660 & 0.134 & 0.841 & 0.435 & 0.463 & 0.894 \\
RLD $(30-40 \mathrm{~cm})$ & $\mathbf{0 . 0 0 0}$ & $\mathbf{0 . 0 0 0}$ & 0.196 & $\mathbf{0 . 0 0 9}$ & 0.075 & 0.312 & 0.819 & 0.101 \\
RLD (40 - 50 cm) & $\mathbf{0 . 0 0 0}$ & $\mathbf{0 . 0 0 0}$ & 0.573 & $\mathbf{0 . 0 0 0}$ & 0.562 & 0.685 & 0.196 & 0.089 \\
RLD (50 - 60 cm) & $\mathbf{0 . 0 0 0}$ & $\mathbf{0 . 0 0 3}$ & 0.235 & $\mathbf{0 . 0 0 1}$ & 0.239 & 0.909 & 0.549 & 0.902 \\
Shoot: root ratio & $\mathbf{0 . 0 0 0}$ & $\mathbf{0 . 0 0 0}$ & $\mathbf{0 . 0 0 0}$ & $\mathbf{0 . 0 0 1}$ & 0.493 & 0.981 & 0.957 & 0.776 \\
\hline
\end{tabular}

effect gradually increased with increasing soil depth. Irrigation did not change root length significantly, thus Figure 2 shows root length as average over Irr+ and Irr- treatments. Total root length was generally higher throughout all soil depths when winter wheat was cultivated in topsoil containing high concentrations of $\mathrm{P}$ (Figure 2, Table 2). This finding is in line with the results from a rhizotron study with wheat [26] showing that P deficiency in the topsoil resulted in decreased biomass of subsoil roots. Plants growing under conditions of low $\mathrm{P}$ supply particularly promote topsoil foraging by increased density and elongation of shallow lateral roots [27].

The positive effect of continuous pores on the root length of wheat in our study was much more evident in treatments with high $\mathrm{P}$ concentrations in the topsoil, indicating that suitable growing conditions in the topsoil along with adequate structure of the subsoil are advantageous for extensive exploration of 
subsoil resources.

Further analysis of the treatments with continuous vertical pores revealed that many wheat roots had reached the lower segment by growing through the large vertical pores in the middle segment. The share of roots growing inside the pore increased with soil depth from $38 \%$ in $20-30 \mathrm{~cm}$ to $64 \%$ in $50-60 \mathrm{~cm}$ (Figure 3 ). In earlier studies, the proportion of roots in CVPs varied widely from $<10 \%$ [28] to near $100 \%$ [29], probably depending on soil properties such as penetration resistance and CVP angle [18]. However, previous studies generally revealed an increasing share of roots in CVPs with soil depth in compacted soil layers [28] [30]. In the bulk soil, presence of continuous pores resulted in decreased root length in $20-40 \mathrm{~cm}$ but increased root length in $40-60 \mathrm{~cm}$ soil depth (Figure 4). Hence, vertical pores shifted the root system towards deeper soil layers. As mentioned above, water supply did not have a marked effect on the root

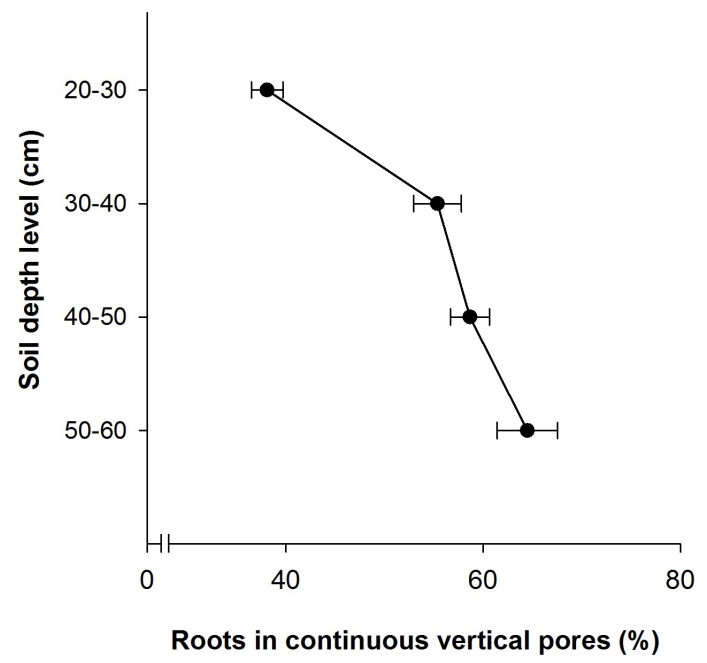

Figure 3. Percentage of roots in continuous vertical pores averaged over all treatments. Error bars represent standard errors.

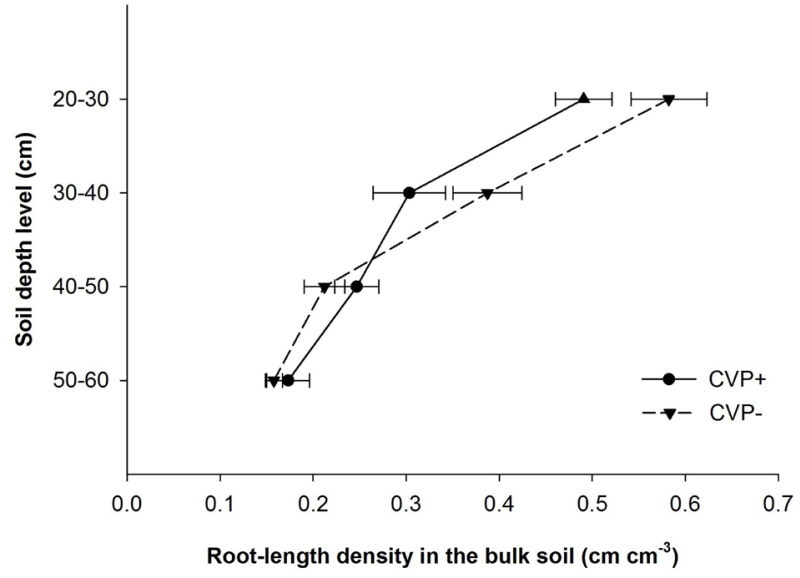

Figure 4. Root length density in the bulk soil as influenced by the presence of continuous vertical pores averaged over all $\mathrm{P}$ supply and irrigation treatments. CVP: Continuous vertical pores. Error bars represent standard errors. 
length of wheat. Merely in the columns with continuous vertical pores, slightly but in significantly increased root length at drought was observed in the deeper soil layers (data not shown). Higher root length under deficit irrigation was reported previously [31]. Deep roots are considered as beneficial for increasing the amount of subsoil moisture accessible by the root system [32]. The reason for the fact that in our study no pronounced effects were observed may be that crops were exposed to water stress merely during the last stage of the experiment.

\subsection{Shoot}

Presence of continuous vertical pores generally had a positive effect on shoot dry matter and $\mathrm{N}$ uptake of wheat, but the magnitude of the effect was different between treatments (Figure 5(a) and Figure 5(b), Table 2). In columns with low soil moisture in the topsoil and high $\mathrm{P}$ concentration in the topsoil, presence of macropores in the subsoil increased shoot dry matter by $66 \%$; in contrast, with irrigation the beneficial effect of macropores on shoot dry matter was only $39 \%$ (Table 3). For $\mathrm{N}$ uptake, the relations were similar (101\% vs. 62\%), likewise for

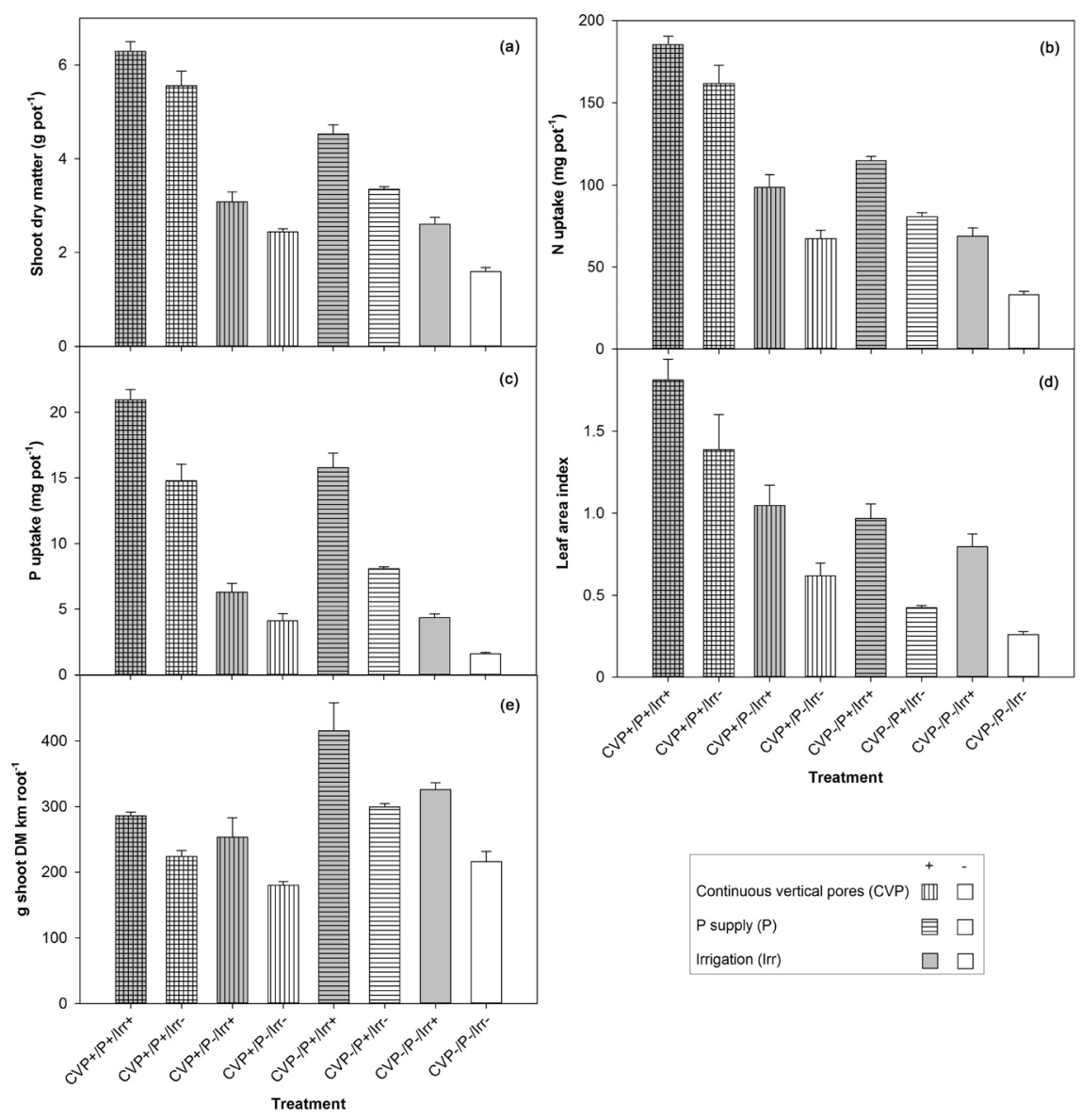

Figure 5. Treatment effects on (a) shoot dry matter; (b) N uptake; (c) P uptake; (d) leaf area index and (e) the ratio of shoot dry matter to total root length of winter wheat. CVP: Continuous vertical pores; P: P supply in the topsoil; Irr: Irrigation. Error bars represent standard errors. 
Table 3. Pairwise comparison of (a) shoot dry matter. (b) $\mathrm{N}$ uptake. (c) P uptake and (d) leaf area index of winter wheat. Differences between treatments are indicated in percentage increases or decreases (\%). Significant differences between treatments (one factorial ANOVA with tukey tests. $\mathrm{p}<0.05$ ) are highlighted in bold.

\begin{tabular}{|c|c|c|c|c|c|c|c|c|}
\hline Treatment & $\mathrm{CVP}+/ \mathrm{P}+/ \mathrm{Irr}+$ & $\mathrm{VP}+/ \mathrm{P}+/ \mathrm{Irr}-$ & $\mathrm{CVP}+/ \mathrm{P}-/ \mathrm{Irr}+$ & $\mathrm{CVP}+/ \mathrm{P}-/ \mathrm{Irr}-$ & $\mathrm{CVP} / \mathrm{P}+/ \mathrm{Irr}+$ & $\mathrm{CVP} / \mathrm{P}+/ \mathrm{Irr}-$ & CVP-/P-/Irr+ & CVP-/P-/Irr- \\
\hline \multicolumn{9}{|c|}{ shoot dry matter } \\
\hline $\mathrm{CVP}+/ \mathrm{P}+/ \mathrm{Irr}+$ & 0.0 & 13.1 & 104.3 & 158.4 & 38.9 & 87.4 & 142.0 & 295.8 \\
\hline $\mathrm{CVP}+/ \mathrm{P}+/ \mathrm{Irr}-$ & -11.6 & 0.0 & 80.6 & 128.4 & 22.8 & 65.7 & 113.9 & 249.8 \\
\hline $\mathrm{CVP}+/ \mathrm{P}-/ \mathrm{Irr}+$ & -51.1 & -44.6 & 0.0 & 26.5 & -32.0 & -8.3 & 18.5 & 93.7 \\
\hline $\mathrm{CVP}+/ \mathrm{P}-/ \mathrm{Irr}-$ & -61.3 & -56.2 & -20.9 & 0.0 & -46.2 & -27.5 & -6.3 & 53.1 \\
\hline CVP-/P+/Irr+ & -28.0 & -18.6 & 47.1 & 86.0 & 0.0 & 34.9 & 74.2 & 184.9 \\
\hline CVP-/P+/Irr- & -46.6 & -39.6 & 9.0 & 37.9 & -25.9 & 0.0 & 29.1 & 111.2 \\
\hline CVP-/P-/Irr+ & -58.7 & -53.3 & -15.6 & 6.8 & -42.6 & -22.6 & 0.0 & 63.5 \\
\hline CVP-/P-/Irr- & -74.7 & -71.4 & -48.4 & -34.7 & -64.9 & -52.6 & -38.8 & 0.0 \\
\hline \multicolumn{9}{|c|}{$\mathrm{N}$ uptake } \\
\hline $\mathrm{CVP}+/ \mathrm{P}+/ \mathrm{Irr}+$ & 0.0 & 14.6 & 88.0 & 176.5 & 61.6 & 130.4 & 169.9 & 460.9 \\
\hline $\mathrm{CVP}+/ \mathrm{P}+/ \mathrm{Irr}-$ & -12.8 & 0.0 & 64.0 & 141.2 & 41.0 & 101.1 & 135.5 & 389.3 \\
\hline $\mathrm{CVP}+/ \mathrm{P}-/ \mathrm{Irr}+$ & -46.8 & -39.0 & 0.0 & 47.1 & -14.0 & 22.6 & 43.6 & 198.3 \\
\hline $\mathrm{CVP}+/ \mathrm{P}-/ \mathrm{Irr}-$ & -63.8 & -58.5 & -32.0 & 0.0 & -41.5 & -16.7 & -2.4 & 102.8 \\
\hline $\mathrm{CVP}-/ \mathrm{P}+/ \mathrm{Irr}+$ & -38.1 & -29.1 & 16.3 & 71.1 & 0.0 & 42.6 & 67.0 & 247.0 \\
\hline CVP-/P+/Irr- & -56.6 & -50.3 & -18.4 & 20.0 & -29.9 & 0.0 & 17.1 & 143.4 \\
\hline CVP-/P-/Irr+ & -63.0 & -57.5 & -30.3 & 2.4 & -40.1 & -14.6 & 0.0 & 107.8 \\
\hline CVP-/P-/Irr- & -82.2 & -79.6 & -66.5 & -50.7 & -71.2 & -58.9 & -51.9 & 0.0 \\
\hline \multicolumn{9}{|c|}{ P uptake } \\
\hline $\mathrm{CVP}+/ \mathrm{P}+/ \mathrm{Irr}+$ & 0.0 & 41.7 & 232.2 & 410.0 & 32.7 & 158.8 & 382.2 & 1213.2 \\
\hline $\mathrm{CVP}+/ \mathrm{P}+/ \mathrm{Irr}-$ & -29.4 & 0.0 & 134.4 & 260.0 & -6.3 & 82.7 & 240.3 & 826.8 \\
\hline $\mathrm{CVP}+/ \mathrm{P}-/ \mathrm{Irr}+$ & -69.9 & -57.3 & 0.0 & 53.5 & -60.0 & -22.1 & 45.2 & 295.3 \\
\hline CVP+/P-/Irr- & -80.4 & -72.2 & -34.9 & 0.0 & -74.0 & -49.3 & -5.5 & 157.5 \\
\hline CVP-/P+/Irr+ & -24.7 & 6.7 & 150.2 & 284.2 & 0.0 & 95.0 & 263.3 & 889.3 \\
\hline CVP-/P+/Irr- & -61.4 & -45.3 & 28.3 & 97.1 & -48.7 & 0.0 & 86.3 & 407.4 \\
\hline CVP-/P-/Irr+ & -79.3 & -70.6 & -31.1 & 5.8 & -72.5 & -46.3 & 0.0 & 172.3 \\
\hline CVP-/P-/Irr- & -92.4 & -89.2 & -74.7 & -61.2 & -89.9 & -80.3 & -63.3 & 0.0 \\
\hline \multicolumn{9}{|c|}{ Leaf area index } \\
\hline $\mathrm{CVP}+/ \mathrm{P}+/ \mathrm{Irr}+$ & 0.0 & 30.4 & 73.0 & 192.3 & 86.8 & 326.5 & 128.1 & 591.3 \\
\hline $\mathrm{CVP}+/ \mathrm{P}+/ \mathrm{Irr}-$ & -23.3 & 0.0 & 32.6 & 124.1 & 43.2 & 227.0 & 74.9 & 430.0 \\
\hline $\mathrm{CVP}+/ \mathrm{P}-/ \mathrm{Irr}+$ & -42.2 & -24.6 & 0.0 & 69.0 & 8.0 & 146.5 & 31.8 & 299.6 \\
\hline $\mathrm{CVP}+/ \mathrm{P}-/ \mathrm{Irr}-$ & -65.8 & -55.4 & -40.8 & 0.0 & -36.1 & 45.9 & -22.0 & 136.5 \\
\hline CVP-/P+/Irr+ & -46.5 & -30.2 & -7.4 & 56.5 & 0.0 & 128.3 & 22.1 & 270.1 \\
\hline CVP-/P+/Irr- & -76.6 & -69.4 & -59.4 & -31.5 & -56.2 & 0.0 & -46.5 & 62.1 \\
\hline CVP-/P-/Irr+ & -56.2 & -42.8 & -24.2 & 28.2 & -18.1 & 87.0 & 0.0 & 203.1 \\
\hline CVP-/P-/Irr- & -85.5 & -81.1 & -75.0 & -57.7 & -73.0 & -38.3 & -67.0 & 0.0 \\
\hline
\end{tabular}


P uptake (83\% vs. 33\%). Thus, the effect of continuous vertical pores in our experiment can be explained primarily with improved accessibility to water stored in deep soil layers. An earlier study [33] showed that barley plants grew better in pots containing a network of narrow pores than in presence of large artificial pores, which was explained mainly by poor root-soil contact and impeded access to the compacted pore walls. However, the experimental pots did not contain a water saturated soil compartment in the deep soil.

When irrigation was ceased, presence of vertical pores in the middle segment increased P uptake from 8.1 to $14.8 \mathrm{mg} /$ pot $(+83 \%)$ when the topsoil was rich in nutrients, but from 1.6 to $4.1 \mathrm{mg} /$ pot $(+158 \%)$ when $\mathrm{P}$ concentrations in the topsoil were low (Figure 5(c)). Apparently, improved access to water and phosphorous in the subsoil becomes relatively more important under conditions of $\mathrm{P}$ deficiency in the topsoil. Despite the fact that vertical pores enhanced root length in the subsoil and the pores were coated with earthworm feces rich in nutrients, it cannot be clarified whether enhanced $\mathrm{P}$ uptake in presence of vertical pores is based on increased $\mathrm{P}$ acquisition from the subsoil.

Whereas $\mathrm{P}$ uptake from CVP coatings has not yet been quantified, $\mathrm{P}$ uptake from the subsoil largely depends on soil properties and growing conditions and varies between 3\% - 4\% [34] and 85\% [35] of total P uptake. Presumably, to some extent the effect of pores can also be based on elevated $\mathrm{P}$ uptake from the topsoil as a consequence of additional water uptake from deep soil. In total numbers, however, the effect of vertical pores on $\mathrm{P}$ uptake into the shoot was more pronounced when $\mathrm{P}$ concentrations in the topsoil were elevated (Figure $5(c))$. Our results clearly indicate that favorable topsoil conditions enable crops to draw more benefit from subsoil resources.

It is important to note that the beneficial effect of continuous vertical pores on shoot dry-matter of wheat, as seen in the optimum treatment $(\mathrm{Irr}+\mathrm{P}+)$, increased at drought $(\mathrm{Irr}-/ \mathrm{P}+)$ but decreased at $\mathrm{P}$ deficiency $(\mathrm{Irr}+/ \mathrm{P}-)$. Hence, the deeper root system in the columns with continuous vertical pores presumably facilitated water uptake from the deep soil, whereas it was less favorable for $\mathrm{P}$ uptake, which primarily takes place in the topsoil. In general, wheat cultivated in topsoil with elevated $\mathrm{P}$ concentrations yielded approximately twice as much shoot dry matter than wheat cultivated in topsoil with low $\mathrm{P}$ concentrations. $\mathrm{P}$ uptake into the shoot more than tripled on average with elevated P concentrations in the topsoil.

Water stress during the last stage of the experiment reduced shoot dry matter of wheat by between $13 \%$ and $63 \%$, depending on presence of continuous vertical pores and $\mathrm{P}$ concentrations in the topsoil (Table 3 ). Since many leaves already withered at harvest, the response to water stress as measured by leaf area index was much more evident (Figure 5(d)). It is noteworthy that in columns with elevated $\mathrm{P}$ concentrations in the topsoil but without vertical pores in the middle segment, irrigation increased shoot dry matter yield from 3.4 to $4.5 \mathrm{~g} / \mathrm{pot}$, whereas unwatered columns with vertical pores in the middle segment yielded 5.4 
g/pot. Hence, the irrigation in our experiment did not fully equalize the water stress.

\subsection{Shoot: Root Ratio}

Enhanced nutrient concentrations in the topsoil and irrigation increased the shoot: root ratio (Figure 5(e)). Plants typically respond to $\mathrm{P}$ deficiency through increased carbon allocation to roots [36]. Preferential partitioning of photosynthates to the roots with decreasing fertilizer concentration has repeatedly been reported [37] [38] and occurs particularly under deficiencies of nutrients mobile in the phloem such as nitrogen and phosphorus [39]. Accordingly, drought can decrease the shoot: root ratio [40] [41] [42], which can be understood as a shift of allocation of phytosynthates towards water obtaining organs.

Vertical pores in the subsoil generally decreased the ratio of shoot mass to root length (Figure 5(e)). It is important to note that depending on treatment and soil depth, root diameter was either not affected or increased (data not shown). Accordingly, a previous field study [43] showed that increased CVP density rather increased the average diameter of a cereal root system. Hence, in our experiment decreased shoot: root ratio was not caused by a higher share of thin roots but by facilitation of root elongation through vertical pores.

Roots are a major sink for carbon and unnecessarily large root systems can reduce water efficiency and even grain yield [44]. Clearly, modern wheat varieties tend to have higher yield potential, higher harvest index and greater shoot: root ratio than old varieties [45]. On the other hand, low shoot: root ratio can reduce drought stress [46]. Hence, large vertical pores in the subsoil cannot necessarily be considered as beneficial for increasing yield under favorable growing conditions, but they can potentially contribute to drought tolerance.

\section{Conclusions}

It has been suggested that increasing CVP densities by cultivating taprooted crops or promoting anecic earthworms can be an element of strategies for soil fertility building [47]. Our study revealed that the effects of large vertical pores on crop growth largely depend on environmental conditions. Our hypothesis that beneficial effects of CVPs on root and shoot growth of winter wheat increase with decreasing availability of water was confirmed. Hence, CVPs can increase the resilience of cropping systems in particular with regard to drought. However, in arable fields, there are no subsoils completely devoid of CVPs. Our experiment was not designed to study how many CVPs per area unit are necessary to enhance uptake of water and nutrients. It still remains an open question whether an increase of CVP density in the field has the potential to increase resilience of cropping systems.

In organic agriculture, it is a general aim to promote the exploration of the solid soil phase by high root-length densities. Concerning this matter, our study indicates that vertical pores can support this goal, but adequate nutrient supply 
to the topsoil is essential. Crops growing under severe nutrient deficiency in early development stages obviously lack the resources to build extensive root systems. Such circumstances cannot be compensated by beneficial growing conditions in the subsoil. Accordingly, in contrast to our hypothesis, our study provides no evidence that the beneficial effect of CVPs on shoot growth of winter wheat increases with decreasing availability of nutrients in the topsoil.

It should be noted that nutrient supply from the drilosphere was probably underestimated in this study. Although the vertical pores were incubated with earthworms before cultivation, the pore wall conditions in a pot experiment do not entirely reflect the pore properties in field, where pores were modified by earthworms and roots probably over decades. The significance of drilosphere properties for root growth and crop performance needs to be addressed in the future.

\section{Acknowledgements}

This study was supported by the BonaRes framework of the German Federal Ministry of Education (Bundesministerium für Bildung und Forschung, BMBF) within the project soil ${ }^{3}$. We thank the staff of the Institute of Organic Agriculture in Bonn for assistance. The last author is grateful for funding by the German Research Foundation (Heisenberg programme, KA 2703/2-1, KA 2703-3-1).

\section{References}

[1] Yunusa, I.M. and Newton, P. (2003) Plants for Amelioration of Subsoil Constraints and Hydrological Control: The Primer-Plant Concept. Plant Soil, 257, 261-281. https://doi.org/10.1023/A:1027381329549

[2] Hagedorn, F. and Bundt, M. (2002) The Age of Preferential Flow Paths. Geoderma, 108, 119-132. https://doi.org/10.1016/S0016-7061(02)00129-5

[3] McKenzie, B.M., Bengough, A.G., Hallett, P.D., Thomas, W.T.B., Forster, B. and McNicol, J.W. (2009) Deep Rooting and Drought Screening of Cereal Crops: A Novel Field-Based Method and Its Application. Field Crops Research, 112, 165-171. https://doi.org/10.1016/j.fcr.2009.02.012

[4] Passioura, J.B. (2002) Soil Conditions and Plant Growth. Plant, Cell \& Environment, 25, 311-318. https://doi.org/10.1046/j.0016-8025.2001.00802.x

[5] Dziejowski, J.E., Rimmer, A. and Steenhuis, T.S. (1997) Preferential Movement of Oxygen in Soils? Soil Science Society of America Journal, 61, 1607-1610. https://doi.org/10.2136/sssaj1997.03615995006100060010x

[6] Pitkänen, J. and Nuutinen, V. (1998) Earthworm Contribution to Infiltration and Surface Runoff after 15 Years of Different Soil Management. Applied Soil Ecology, 9, 411-415. https://doi.org/10.1016/S0929-1393(98)00098-5

[7] Dadfar, H., Allaire, S.E., Bochove, E., Denault, J.-T., Thériault, G. and Charles, A. (2010) Likelihood of Burrow Flow in Canadian Agricultural Lands. Journal of Hydrology, 386, 142-159. https://doi.org/10.1016/j.jhydrol.2010.03.016

[8] Djodjic, F., Börling, K. and Bergström, L. (2004) Phosphorus Leaching in Relation to Soil Type and Soil Phosphorus Content. Journal of Environmental Quality, 33, 
678-684. https://doi.org/10.2134/jeq2004.6780

[9] Li, Y. and Ghodrati, M. (1994) Preferential Transport of Nitrate through Soil Columns Containing Root Channels. Soil Science Society of America Journal, 58, 653-659. https://doi.org/10.2136/sssaj1994.03615995005800030003x

[10] Gaiser, T., Perkons, U., Küpper, P.M., Puschmann, D.U., Peth, S., Kautz, T., Pfeifer, J., Ewert, F., Horn, R. and Köpke, U. (2012) Evidence of Improved Water Uptake from Subsoil by Spring Wheat Following Lucerne in a Temperate Humid Climate. Field Crops Research, 126, 56-62. https://doi.org/10.1016/j.fcr.2011.09.019

[11] Dai, A. (2013) Increasing Drought under Global Warming in Observations and Models. Nature Climate Change, 3, 52-58. https://doi.org/10.1038/nclimate1633

[12] Athmann, M., Kautz, T., Banfield, C., Bauke, S., Hoang, D.T., Lüsebrink, M., Pausch, J., Amelung, W., Kuzyakov, Y. and Köpke, U. (2017) Six Months of L. terrestris L. Activity in Root-Formed Biopores Increases Nutrient Availability, Microbial Biomass and Enzyme Activity. Applied Soil Ecology, 120, 135-142. https://doi.org/10.1016/j.apsoil.2017.08.015

[13] Pankhurst, C.E., Pierret, A., Hawke, B.G. and Kirby, J.M. (2002) Microbiological and Chemical Properties of Soil Associated with Macropores at Different Depths in a Red-Duplex Soil in NSW Australia. Plant Soil, 238, 11-20.

https://doi.org/10.1023/A:1014289632453

[14] Tiunov, A.V. and Scheu, S. (1999) Microbial Respiration, Biomass, Biovolume and Nutrient Status in Burrow Walls of Lumbricus terrestris L. (Lumbricidae). Soil Biology \& Biochemistry, 31, 2039-2048. https://doi.org/10.1016/S0038-0717(99)00127-3

[15] Perkons, U., Kautz, T., Uteau, D., Peth, S., Geier, V., Thomas, K., Lütke Holz, K., Athmann, M., Pude, R. and Köpke, U. (2014) Root-Length Densities of Various Annual Crops Following Crops with Contrasting Root Systems. Soil \& Tillage Research, 137, 50-57. https://doi.org/10.1016/j.still.2013.11.005

[16] Cresswell, H.P. and Kirkegaard, J.A. (1995) Subsoil Amelioration by Plant Roots-The Process and the Evidence. Australian Journal of Soil Research, 33, 221-239. https://doi.org/10.1071/SR9950221

[17] Athmann, M., Kautz, T., Pude, R. and Köpke, U. (2013) Root Growth in Biopores-Evaluation with in Situ Endoscopy. Plant Soil, 371, 179-190. https://doi.org/10.1007/s11104-013-1673-5

[18] Hirth, J.R., McKenzie, B.M. and Tisdall, J.M. (2005) Ability of Seedling Roots of Lolium perenne L. to Penetrate Soil from Artificial Biopores Is Modified by Soil Bulk Density, Biopore Angle and Biopore Relief. Plant Soil, 272, 327-336. https://doi.org/10.1007/s11104-004-5764-1

[19] Lambers, H., Atkin, O.K. and Millenaar, F.F. (2002) Respiratory Patterns in Roots in Relation to Their Functioning. In: Waisel, Y., Eshel, A. and Kafkaki, K., Eds., Plant Roots, The Hidden Half, Marcel Dekker, New York, 521-552. https://doi.org/10.1201/9780203909423.pt6

[20] Lynch, J. and Ho, M. (2005) Rhizoeconomics: Carbon Costs of Phosphorus Acquisition. Plant and Soil, 269, 45-56. https://doi.org/10.1007/s11104-004-1096-4

[21] Paulsen, H.M., Köpke, U., Oberson, A. and Rahmann, G. (2016) Phosphorus-The Predicament of Organic Farming. In: Schnug, E. and De Kok, L.J., Eds., Phosphorus in Agriculture: 100\% Zero, Springer Netherlands, Dordrecht, 195-213. https://doi.org/10.1007/978-94-017-7612-7_10

[22] Kautz, T., Amelung, W., Ewert, F., Gaiser, T., Horn, R., Jahn, R., Javaux, M., Kem- 
na, A., Kuzyakov, Y., Munch, J.-C., Pätzold, S., Peth, S., Scherer, H.W., Schloter, M., Schneider, H., Vanderborght, J., Vetterlein, D., Walter, A., Wiesenberg, G.L.B. and Köpke, U. (2013) Nutrient Acquisition from Arable Subsoils in Temperate Climates: A Review. Soil Biology and Biochemistry, 57, 1003-1022. https://doi.org/10.1016/j.soilbio.2012.09.014

[23] Kautz, T., Lüsebrink, M., Pätzold, S., Vetterlein, D., Pude, R., Athmann, M., Küpper, P.M., Perkons, U. and Köpke, U. (2014) Contribution of Anecic Earthworms to Biopore Formation during Cultivation of Perennial Ley Crops. Pedobiologia, 57, 47-52. https://doi.org/10.1016/j.pedobi.2013.09.008

[24] Mertens, F.M., Pätzold, S. and Welp, G. (2008) Spatial Heterogeneity of Soil Properties and Its Mapping with Apparent Electrical Conductivity. Journal of Plant Nutrition and Soil Science, 171, 146-154. https://doi.org/10.1002/jpln.200625130

[25] Han, E., Kautz, T., Perkons, U., Lüsebrink, M., Pude, R. and Köpke, U. (2015) Quantification of Soil Biopore Density after Perennial Fodder Cropping. Plant Soil, 394, 73-85. https://doi.org/10.1007/s11104-015-2488-3

[26] Bauke, S., Landl, M., Koch, M., Hofmann, D., Nagel, K., Siebers, N., Schnepf, A. and Amelung, W. (2017) Macropore Effects on Phosphorus Acquisition by Wheat Roots-A Rhizotron Study. Plant Soil, 416, 67-82. https://doi.org/10.1007/s11104-017-3194-0

[27] Williamson, L.C., Ribrioux, S.P., Fitter, A.H. and Leyser, H.O. (2001) Phosphate Availability Regulates Root System Architecture in Arabidopsis. Plant Physiology, 126, 875-882. https://doi.org/10.1104/pp.126.2.875

[28] Kautz, T., Perkons, U., Athmann, M., Pude, R. and Köpke, U. (2013) Barley Roots Are Not Constrained to Large-Sized Biopores in the Subsoil of a Deep Haplic Luvisol. Biology and Fertility of Soils, 49, 959-963. https://doi.org/10.1007/s00374-013-0783-9

[29] Ehlers, W., Köpke, U., Hesse, F. and Böhm, W. (1983) Penetration Resistance and Root Growth of Oats in Tilled and Untilled Loess Soil. Soil \& Tillage Research, 3, 261-275. https://doi.org/10.1016/0167-1987(83)90027-2

[30] Nakamoto, T. (1997) The Distribution of Maize Roots as Influenced by Artificial Vertical Macropores. Japanese Journal of Crop Science, 66, 331-332. https://doi.org/10.1626/jcs.66.331

[31] Comas, L., Becker, S., Cruz, V.M., Byrne, P.F. and Dierig, D.A. (2013) Root Traits Contributing to Plant Productivity under Drought. Frontiers in Plant Science, 4, 442. https://doi.org/10.3389/fpls.2013.00442

[32] Wasson, A.P., Richards, R.A., Chatrath, R., Misra, S.C., Prasad, S.V.S., Rebetzke, G.J., Kirkegaard, J.A., Christopher, J. and Watt, M. (2012) Traits and Selection Strategies to Improve Root Systems and Water Uptake in Water-Limited Wheat Crops. Journal of Experimental Botany, 63, 3485-3498. https://doi.org/10.1093/jxb/ers111

[33] Stirzaker, R., Passioura, J. and Wilms, Y. (1996) Soil Structure and Plant Growth: Impact of Bulk Density and Biopores. Plant Soil, 185, 151-162. https://doi.org/10.1007/BF02257571

[34] Barber, S.A. and Mackay, A.D. (1986) Root Growth and Phosphorus and Potassium Uptake by Two Corn Genotypes in the Field. Nutrient Cycling in Agroecosystems, 10, 217-230. https://doi.org/10.1007/BF01049351

[35] Kuhlmann, H. and Baumgärtel, G. (1991) Potential Importance of the Subsoil for the P and Mg Nutrition of Wheat. Plant Soil, 137, 259-266. 
https://doi.org/10.1007/BF00011204

[36] Vance, C.P., Uhde-Stone, C. and Allan, D.L. (2003) Phosphorus Acquisition and Use: Critical Adaptations by Plants for Securing a Nonrenewable Resource. New Phytologist, 157, 423-447. https://doi.org/10.1046/j.1469-8137.2003.00695.x

[37] Kang, J.-G. and van Iersel, M.W. (2004) Nutrient Solution Concentration Affects Shoot: Root Ratio, Leaf Area Ratio, and Growth of Subirrigated Salvia (Salvia splendens). Horticultural Science, 39, 49-54.

[38] Sattelmacher, B., Klotz, F. and Marschner, H. (1990) Influence of the Nitrogen Level on Root Growth and Morphology of Two Potato Varieties Differing in Nitrogen Acquisition. Plant Soil, 123, 131-137. https://doi.org/10.1007/BF00011258

[39] Marschner, H., Kirkby, E. and Cakmak, I. (1996) Effect of Mineral Nutritional Status on Shoot-Root Partitioning of Photoassimilates and Cycling of Mineral Nutrients. Journal of Experimental Botany, 47, 1255-1263. https://doi.org/10.1093/jxb/47.Special_Issue.1255

[40] Liu, F. and Stützel, H. (2004) Biomass Partitioning, Specific Leaf Area, and Water Use Efficiency of Vegetable Amaranth (Amaranthus spp.) in Response to Drought Stress. Scientia Horticulturae, 102, 15-27. https://doi.org/10.1016/j.scienta.2003.11.014

[41] Pace, P., Cralle, H.T., El-Halawany, S.H., Cothren, J.T. and Senseman, S.A. (1999) Drought-Induced Changes in Shoot and Root Growth of Young Cotton Plants. Journal of Cotton Science, 3, 183-187.

[42] Shaw, B., Thomas, T. and Cooke, D. (2002) Responses of Sugar Beet (Beta vulgaris L.) to Drought and Nutrient Deficiency Stress. Plant Growth Regulation, 37, 77-83. https://doi.org/10.1023/A:1020381513976

[43] Han, E., Kautz, T. and Köpke, U. (2016) Precrop Root System Determines Root Diameter of Subsequent Crop. Biology and Fertility of Soils, 52, 113-118. https://doi.org/10.1007/s00374-015-1049-5

[44] Passioura, J.B. (1983) Roots and Drought Resistance. Agricultural Water Management, 7, 265-280. https://doi.org/10.1016/0378-3774(83)90089-6

[45] Siddique, K., Belford, R. and Tennant, D. (1990) Root: Shoot Ratios of Old and Modern, Tall and Semi-Dwarf Wheats in a Mediterranean Environment. Plant Soil, 121, 89-98. https://doi.org/10.1007/BF00013101

[46] Karcher, D.E., Richardson, M.D., Hignight, K. and Rush, D. (2008) Drought Tolerance of Tall Fescue Populations Selected for High Root/Shoot Ratios and Summer Survival. Crop Science, 48, 771-777. https://doi.org/10.2135/cropsci2007.05.0272

[47] Köpke, U., Athmann, M., Han, E. and Kautz, T. (2015) Optimising Cropping Techniques for Nutrient and Environmental Management in Organic Agriculture. Sustainable Agriculture Research, 4, 15-25. https://doi.org/10.5539/sar.v4n3p15 